\title{
Evaluasi Penerimaan Sistem Otomasi Perpustakaan Senayan Library Management System (SLiMS) dengan Pendekatan Technology Acceptance Model (TAM) di UPT Perpustakaan Politeknik Negeri Sriwijaya
}

\author{
Roman Saputra', Budhi Santoso ${ }^{2}$, M. Syawaludin ${ }^{3}$ \\ ${ }^{1}$ Prodi Ilmu Perpustaakaan, Fakultas Adab dan Humaniora, UIN Raden Fatah Palembang \\ ${ }^{2}$ Prodi Ilmu Perpustaakaan, Fakultas Adab dan Humaniora, UIN Raden Fatah Palembang \\ ${ }^{3}$ Prodi Politik Islam, Fakultas Adab dan Humaniora, UIN Raden Fatah Palembang \\ *Korespondensi: romansaputra83@gmail.com
}

\begin{abstract}
This study aims to determine the acceptance of the Senayan Library Management System (SLiMS) Library Automation System to the Pemustaka by Using the Technology Acceptance Model (TAM) Approach in the Technical Provider Unit (UPT) of the Polytechnic State Library of Sriwijaya. This type of research is a quantitative study with a descriptive approach. The population is the number of library members visiting the Sriwijaya State Polytechnic Library Palembang for one year from January 2018 to December 2018, and the study sample was taken as many as 100 respondents. The results showed that the library automation system, in this case based on the Senayan Library Management System (SLiMS), was acceptable among users. The calculation of questionnaire answers from 100 samples resulted in an average of 3.99 total sub-variables in the range 3.40 4.20 which are included in the high category. This means that the application of the automation system to the library can be easily accessed and provides many benefits for users who are looking for the information needed. It was concluded that the automation system at the Sriwijaya State Polytechnic Library UPT analysis of SliMS software acceptance received high marks
\end{abstract}

Keywords: Library's automation system; Senayan Library Management System;

Technology Acceptance Model approach

\begin{abstract}
Abstrak
Penelitian ini bertujuan untuk mengetahui Penerimaan Sistem Otomasi Perpustakaan Berbasis Senayan Library Management System (SLiMS) Kepada Pemustaka dengan Menggunakan Pendekatan Technology Acceptance Model (TAM) di Unit Penyedia Teknis (UPT) Perpustakaan Politeknik Negeri Sriwijaya. Jenis penelitian yang digunakan adalah penelitian kuantitatif dengan metode pendekatan deskriptif. Populasinya adalah jumlah anggota perpustakaan yang berkunjung ke UPT Perpustakaan Politeknik Negeri Sriwijaya Palembang selama satu tahun dari Januari 2018 sampai dengan Desember 2018, dan sampel penelitian diambil sebanyak 100 responden. Hasil penelitian menunjukan bahwa sistem otomasi pada perpustakaan, dalam hal ini berbasis Senayan Library Management System (SLiMS) dapat diterima di kalangan pemustaka. Perhitungan jawaban angket dari 100 sampel menghasilkan rata-rata total subvariabel 3,99 berada pada rentang 3,40 4,20 yang termasuk dalam kategori tinggi. Ini berarti bahwa penerapan sistem otomasi pada perpustakaan dapat dengan mudah diakses dan memberikan banyak manfaat bagi pemustaka yang mencari informasi yang dibutuhkan. Disimpulkan sistem otomasi pada UPT Perpustakaan Politeknik Negeri Sriwijaya analisis penerimaan software SliMS mendapatkan nilai tinggi .

Kata kunci: Sistem Otomasi Perpustakaan, Senayan Library Management System,

Technology Acceptance Model
\end{abstract}

\section{PENDAHULUAN}

Perkembangan teknologi informasi dan komunikasi berjalan secara cepat dari waktu ke waktu. Saat ini dapat ditemukan adanya sentuhan teknologi informasi disemua aspek kehidupan salah satunya yaitu pemanfaatan teknologi informasi dan komunikasi untuk memperoleh informasi secara cepat dan instan. Tuntutan pekerjaan yang serba ingin cepat dan tepat baik penunjang pekerjaan sampai sistem pencarian informasi, semua dituntut untuk menggunakan teknologi, tidak 
terkecuali bagi dunia pendidikan. Mulai dari proses pembelajaran, sarana prasarana hingga pada perpustakaan. Pada bidang pendidikan, perpustakaan menjadi salah satu aspek yang dituntut untuk mengikuti perkembangan dari teknologi informasi khususnya dalam hal pengelolaan informasi, seperti disebutkan dalam Undang-Undang Republik Indonesia No. 43 Tahun 2007 Pasal 14 tentang layanan perpustakaan bahwasanya setiap perpustakaan mengembangkan layanan perpustakaan sesuai dengan kemajuan teknologi informasi dan komunikasi (Republik Indonesia, 2007).

Sesuai dengan subjek yang dilayani perpustakaan terbagi menjadi beberapa jenis yaitu Perpustakaan Nasional; Perpustakaan Umum; Perpustakaan Sekolah/Madrasah; Perpustakaan Perguruan Tinggi; dan Perpustakaan Khusus. Menurut Rahayuningsih (2007), perpustakaan perguruan tinggi adalah perpustakaan yang melayani mahasiswa, dosen, dan karyawan suatu perguruan tinggi tertentu (akademika, universitas, institut, sekolah tinggi dan politeknik). Saat ini layanan perpustakaan perguruan tinggi diharapkan mengembangkan layanan berbasis teknologi informasi dan komunikasi.

Evaluasi penerimaan menggunakan menggunakan konsep Technology Acceptance Model (TAM) perlu dilakukan terutama untuk sistem informasi yang baru diterapkan di institusi perpustakaan. Unit Penyedia Teknis Perpustakaan Politeknik Negeri Sriwijaya Palembang (Polsri) dipilih sebagai lokasi penelitian karena UPT Polsri menjalankan sistem otomasi mengembangkan sistem otomasi terbaru sehingga penulis tertarik untuk melakukan penelitian khususnya tentang evaluasi penerimaan sistem otomasi perpustakaan.

\section{METODE PENELITIAN}

Penelitian ini menggunakan deskritif kuantitatif. Penelitian deskriptif kuantitatif merupakan usaha sadar dan sistematis untuk memberikan jawaban terhadap suatu masalah dan atau mendapatkan informasi lebih mendalam dan luas terhadap suatu fenomena dengan menggunakan tahap-tahap penelitian dengan pendekatan kuantitatif (Yusuf, 2017, p. 62).

\section{Teknik Pengumpulan Data}

Teknik pengumpulan data merupakan bagian dari tahapan penelitian langkah yang cukup strategis karena tujuan utama dari penelitian adalah mendapatkan data untuk dianalisis lebih lanjut. Tanpa mengetahui teknik pengumpulan data, maka peneliti tidak akan mendapatkan data yang memenuhi standar data yang ditetapkan (Sugiyono, 2013, p. 224). Pada penelitian ini insturumen pengumpulan data menggunakan kuesioner. Kuisioner merupakan teknik pengumpulan data yang dilakukan dengan cara memberi seperangkat pertanyaan atau pernyataan tertulis kepada responden untuk kemudian dijawab (Sugiyono, 2013).

Populasi dalam penelitian ini adalah pengunjung perpustakaan dari bulan Januari sampai dengan Deseber 2018 sebanyak 25.222 pengunjung. Sampel adalah sebagian atau wakil dari populasi yang diteliti (Arikunto, 2010). Dalam penelitian ini jumlah sampel dihitung dengan rumus dari Taro yammane dengan tingkat kesalahan sebesar 10\% didaptkan hasil 99.605 sampel dibulatkan menjadi 100 sampel.

. Data yang terkumpul kemudian dianalisis menggunakan analisis deskriptif. Menurut Azwar (2010) analisis deskriptif bertujuan untuk memberikan deskriptif mengenai subjek penelitian berdasarkan data dari variabel yang diperoleh dari kelompok subjek yang diteliti dan tidak bermaksudkan untuk menguji hipotesis. Adapun dalam analisis ini penulis mengunakan rumus Mean, rumus mean digunakan untuk mengetahui nilai rata-rata dari setiap butir instrumen.

\section{HASIL DAN PEMBAHASAN}

Analisis deskriptif dilakukan untuk mengetahui penerimaan dengan menggunakan pendekatan Technology Acceptance Model (TAM) yang dilakukan dengan 6 sub variabel yaitu kebermanfaatan, kemudahan penggunaan, sikap penggunaan, intensitas perilaku pengguna, penggunaan secara aktual, penerimaan. Berdasarkan hasil kuesioner yang berjumlah 34 butir 
Tadwin: Jurnal Ilmu Perpustakaan dan Informasi, Vol 1 (1) 2020, Halaman: 50-57

Copyright (02020

Available Online at: http://jurnal.radenfatah.ac.id/index.php/tadwin

pernyataan yang diajukan kepada 100 responden, kemudian data disajikan dalam bentuk tabel dan dihitung dengan rumus mean dan grand mean.

Hasil perhitungan keseluruhan dari sub variabel kebermanfaatan, diperoleh nilai total rata-rata 3,913. Dapat disimpulkan bahwa evaluasi kebermanfaatan pada website UPT Perpustakaan Politeknik Negeri Sriwijaya pada sub variabel kebermanfaatan (Perceived Usefulness) dapat dikategorikan tinggi karena berada antara interval 3,40-4,20.

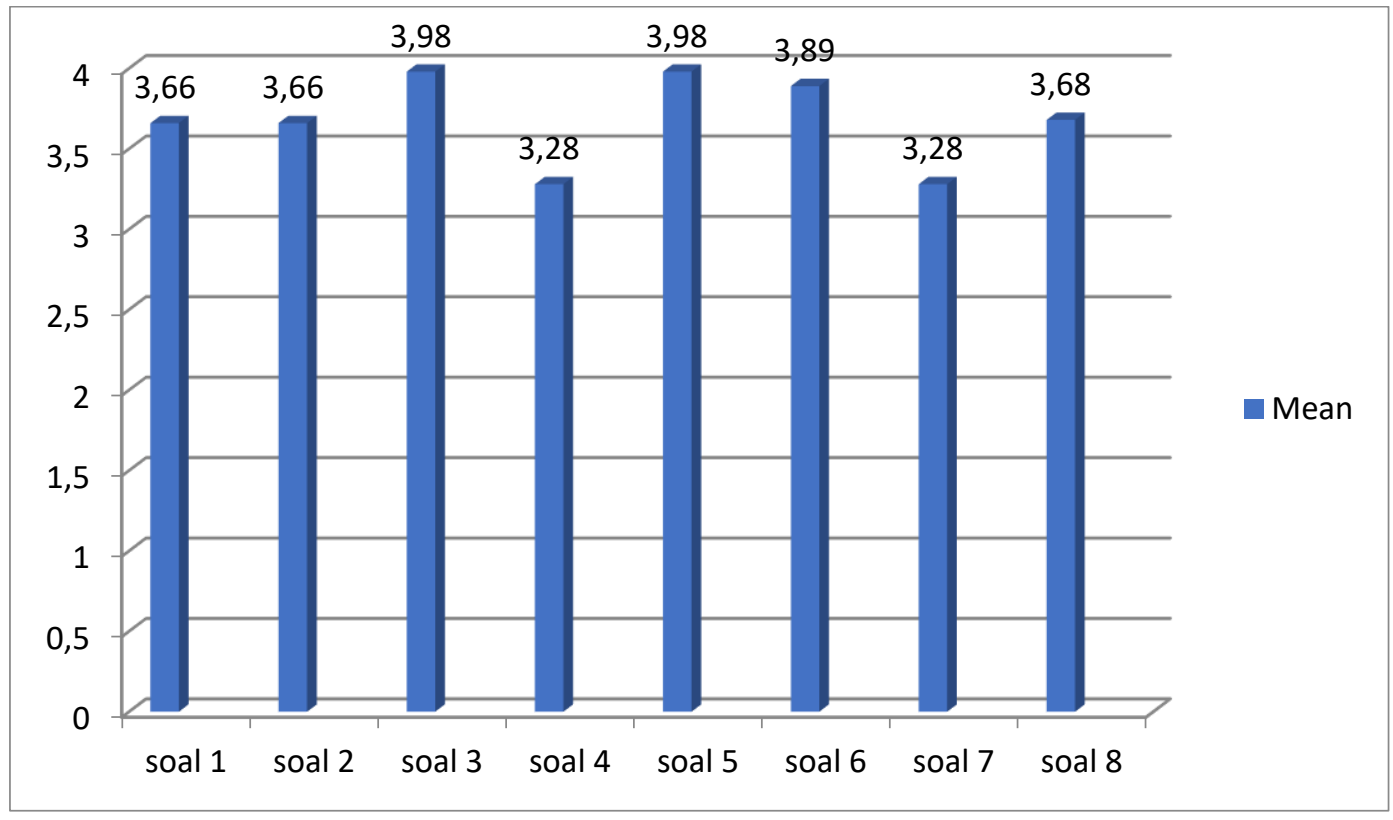

Grafik 1. Diagram Analisis Sub Variabel Kebermanfaatan

Hasil perhitungan keseluruhan dari sub variabel kemudahan penggunaan, diperoleh nilai total ratarata 3,876. Dapat disimpulkan bahwa kemudahan penggunaan (Perceived Ease of Use) pada UPT Perpustakaan Politeknik Negeri Sriwijaya pada sub variabel kemudahan penggunaan (Perceived Ease of Use) dapat dikategorikan tinggi karena berada antara interval 3,40-4,20.

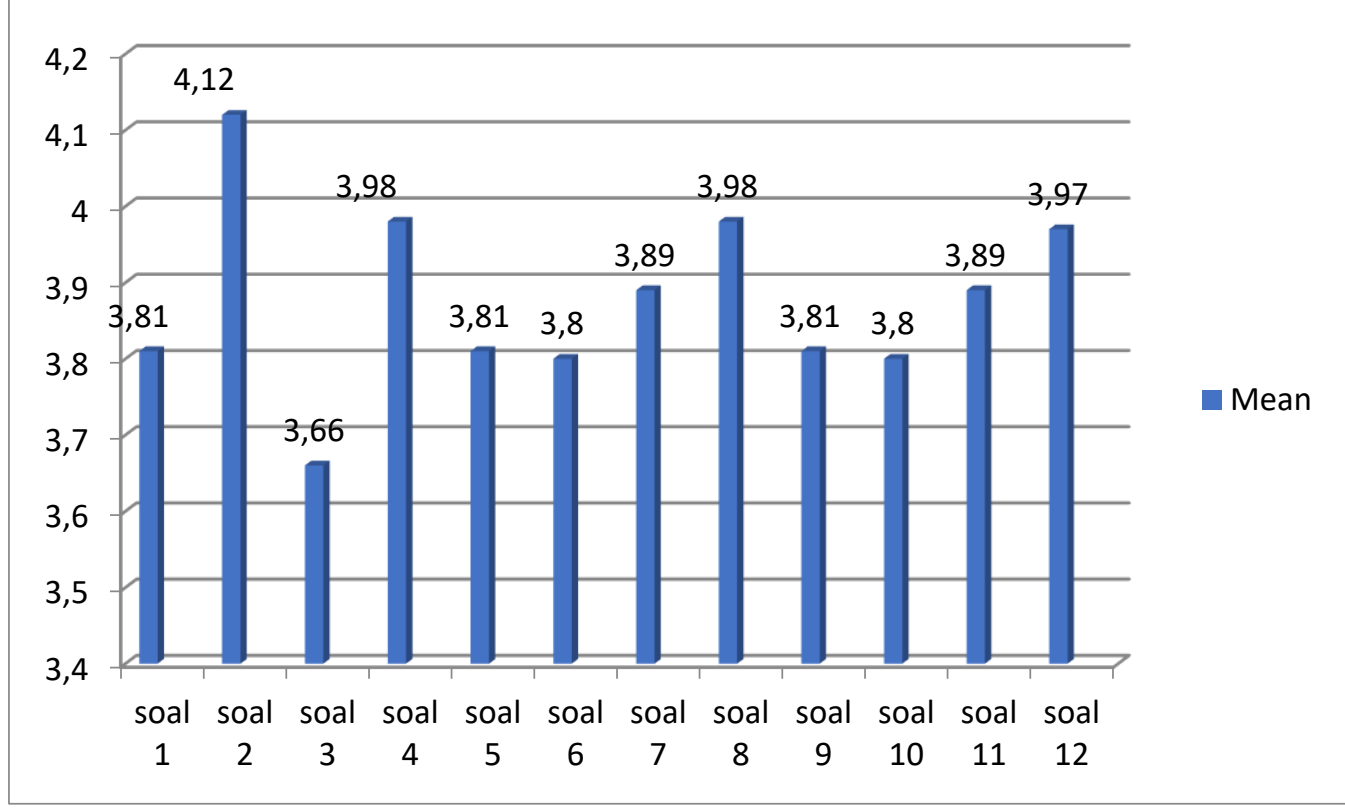


Tadwin: Jurnal Ilmu Perpustakaan dan Informasi, Vol 1 (1) 2020, Halaman: 50-57

Copyright (02020

Available Online at: http://jurnal.radenfatah.ac.id/index.php/tadwin

Grafik 2. Diagram Analisis Subvariabel Kemudahan Penggunaan

Hasil perhitungan keseluruhan dari sub variabel sikap penggunaan, diperoleh nilai total rata-rata 3,93. Dapat disimpulkan bahwa evaluasi kebermanfaatan pada website UPT Perpustakaan Politeknik Negeri Sriwijaya pada sub variabel sikap penggunaan dapat dikategorikan tinggi karena berada antara interval 3,40 - 4,20.

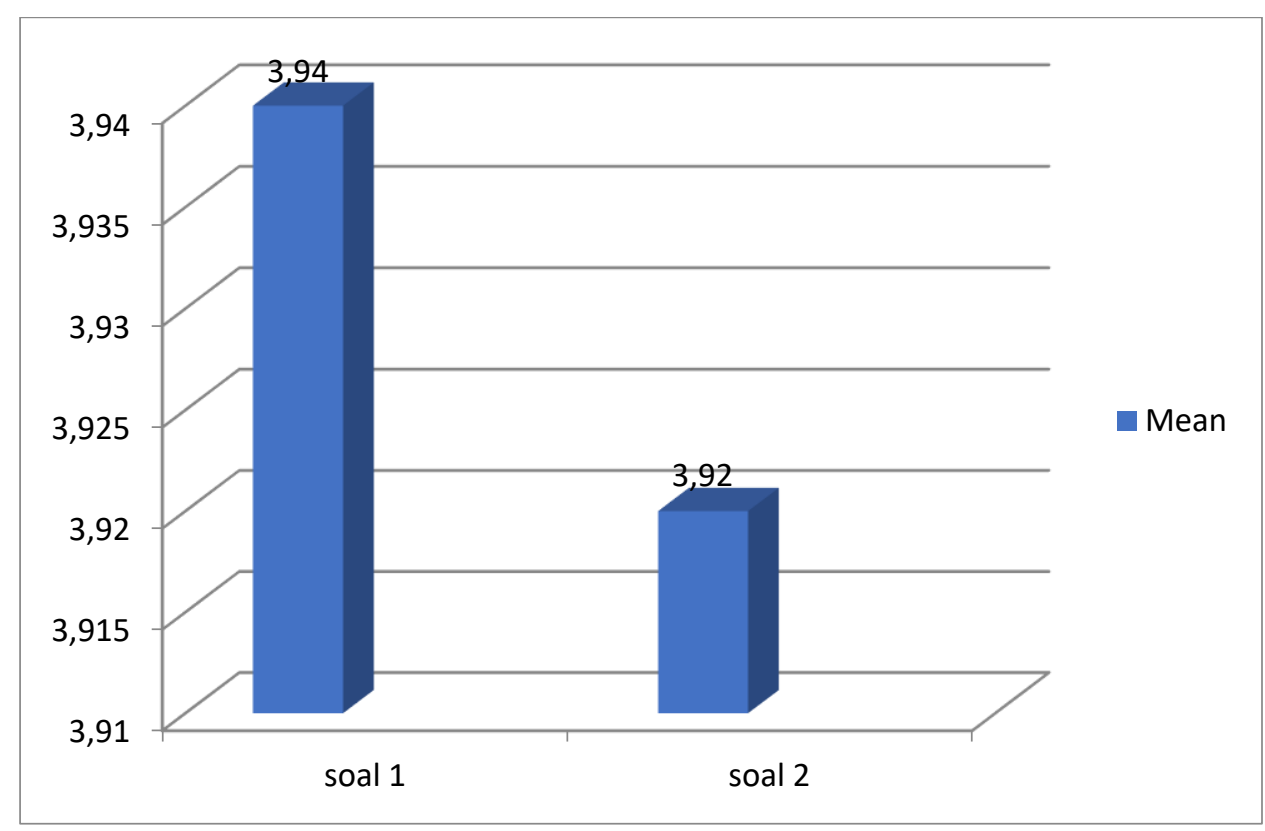

Grafik 3. Diagram Analisis Subvariabel Sikap Pengguna

Hasil perhitungan keseluruhan dari sub variabel intensitas perilaku penggunaan, diperoleh nilai total rata-rata 4,035. Dapat disimpulkan bahwa evaluasi intensitas perilaku pengguna pada website UPT Perpustakaan Politeknik Negeri Sriwijaya dapat dikategorikan tinggi karena berada antara interval $3,40-4,20$.

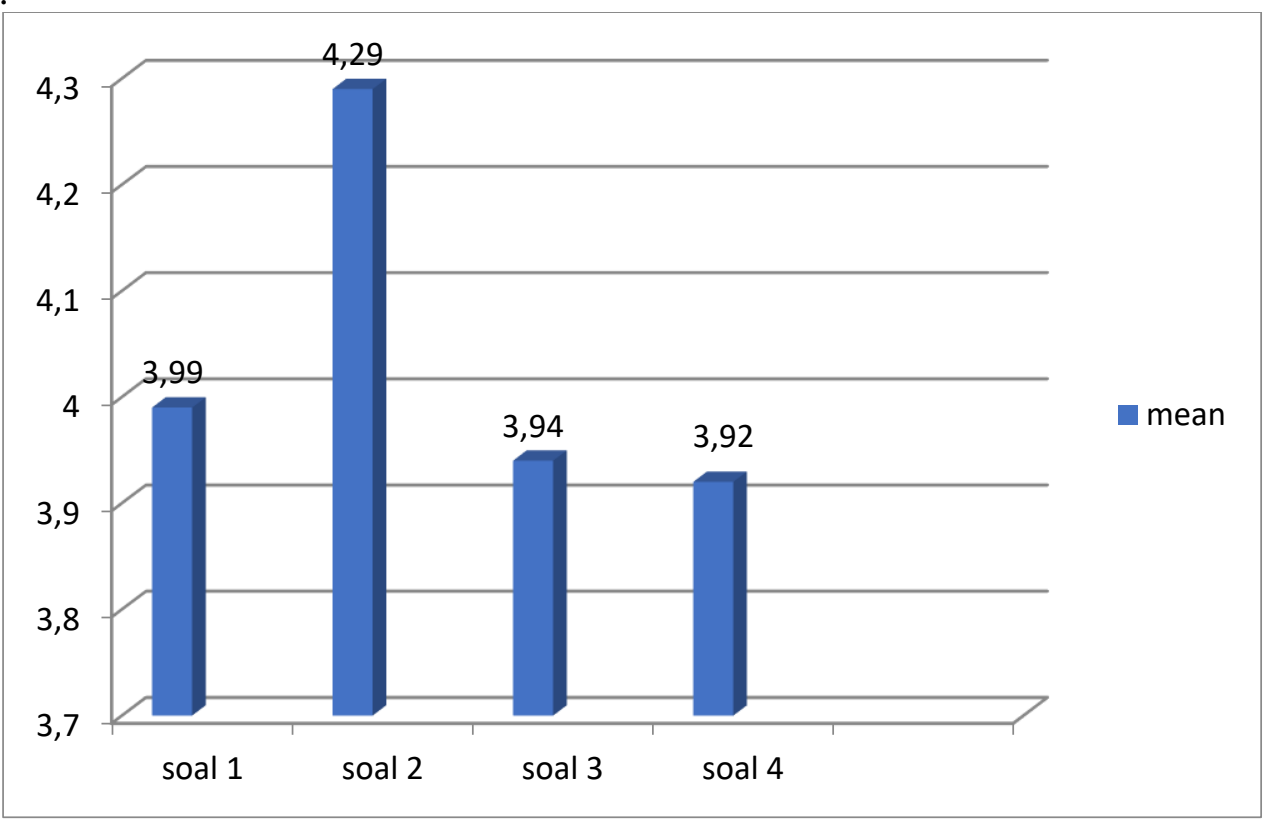

Grafik 4. Diagram Analisis Sub Variabel Intensitas Perilaku Pengguna 
Tadwin: Jurnal Ilmu Perpustakaan dan Informasi, Vol 1 (1) 2020, Halaman: 50-57

Copyright $@ 2020$

Available Online at: http://jurnal.radenfatah.ac.id/index.php/tadwin

Hasil perhitungan keseluruhan dari sub variabel intensitas perilaku penggunaan, diperoleh nilai total rata-rata 4,122. Dapat disimpulkan bahwa evaluasi penggunaan secara aktual pada website UPT Perpustakaan Politeknik Negeri Sriwijaya dapat dikategorikan tinggi karena berada antara interval 3,40-4,20.

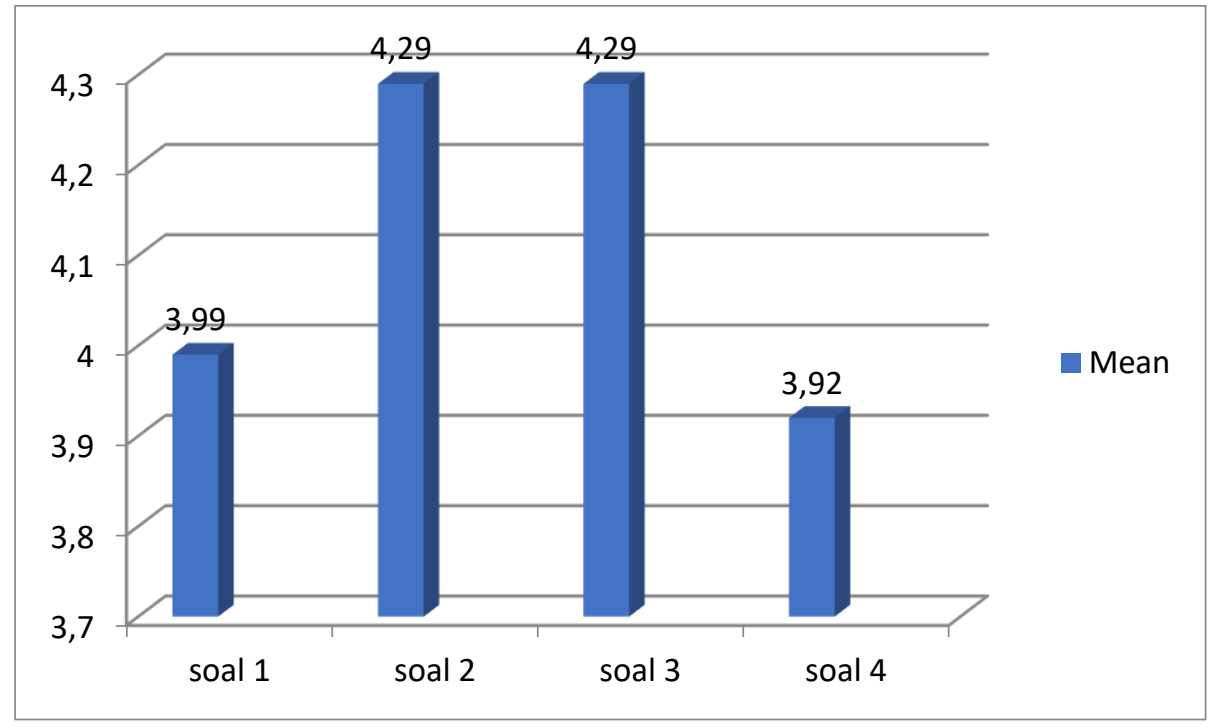

Grafik 5. Diagram Analisis Data Sub Variabel Penggunaan Secara Aktual

Hasil perhitungan keseluruhan dari sub variabel penerimaan, diperoleh nilai total rata-rata 4,104. Dapat disimpulkan bahwa evaluasi penerimaan pada website UPT Perpustakaan Politeknik Negeri Sriwijaya dapat dikategorikan tinggi karena berada antara interval 3,40 - 4,20.

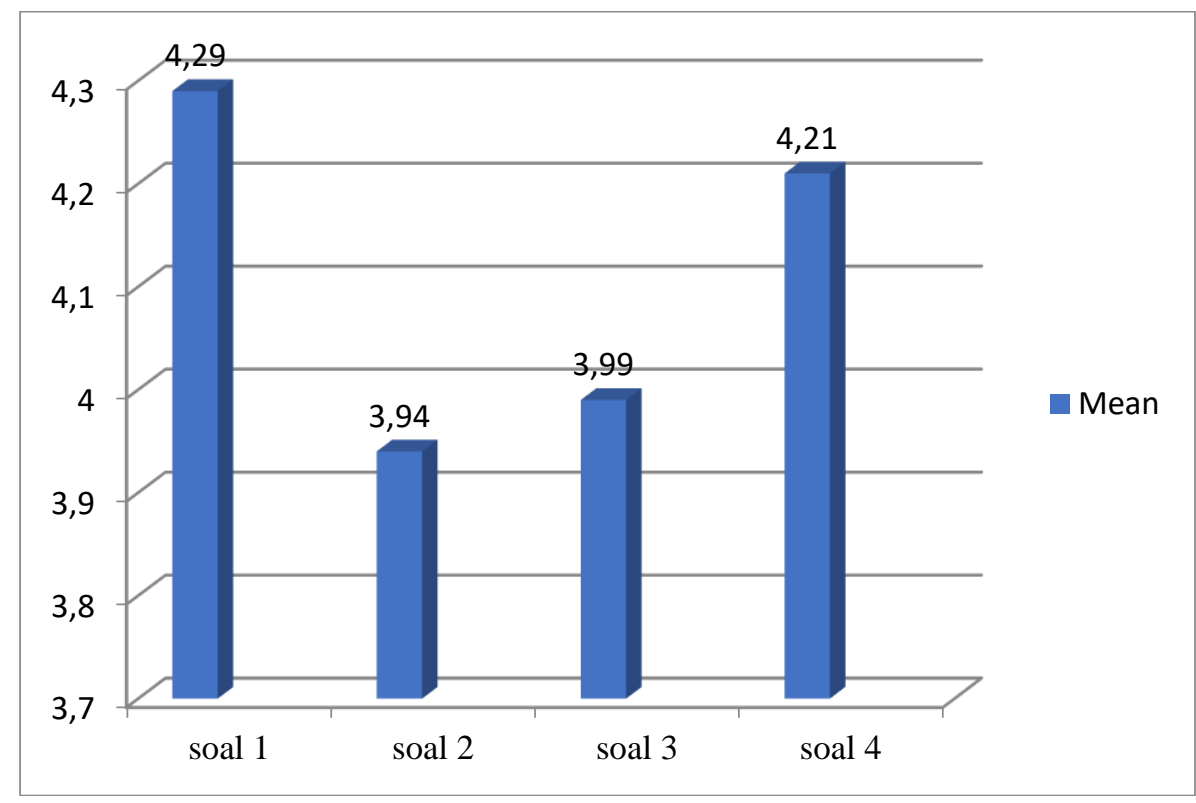

Grafik 6. Diagram Analisis Data Sub Variabel Penerimaan

Berdasarkan rata-rata dari keseluruhan indikator yang telah dijawab responden, maka selajutnya dihitung rata-rata total dari seluruh subvariabel sebagai berikut : 
Tadwin: Jurnal Ilmu Perpustakaan dan Informasi, Vol 1 (1) 2020, Halaman: 50-57

Copyright $@ 2020$

Available Online at: http://jurnal.radenfatah.ac.id/index.php/tadwin

Tabel 1

Hasil Analisis Keseluruhan Variabel Technology Acceptance

Model (TAM)

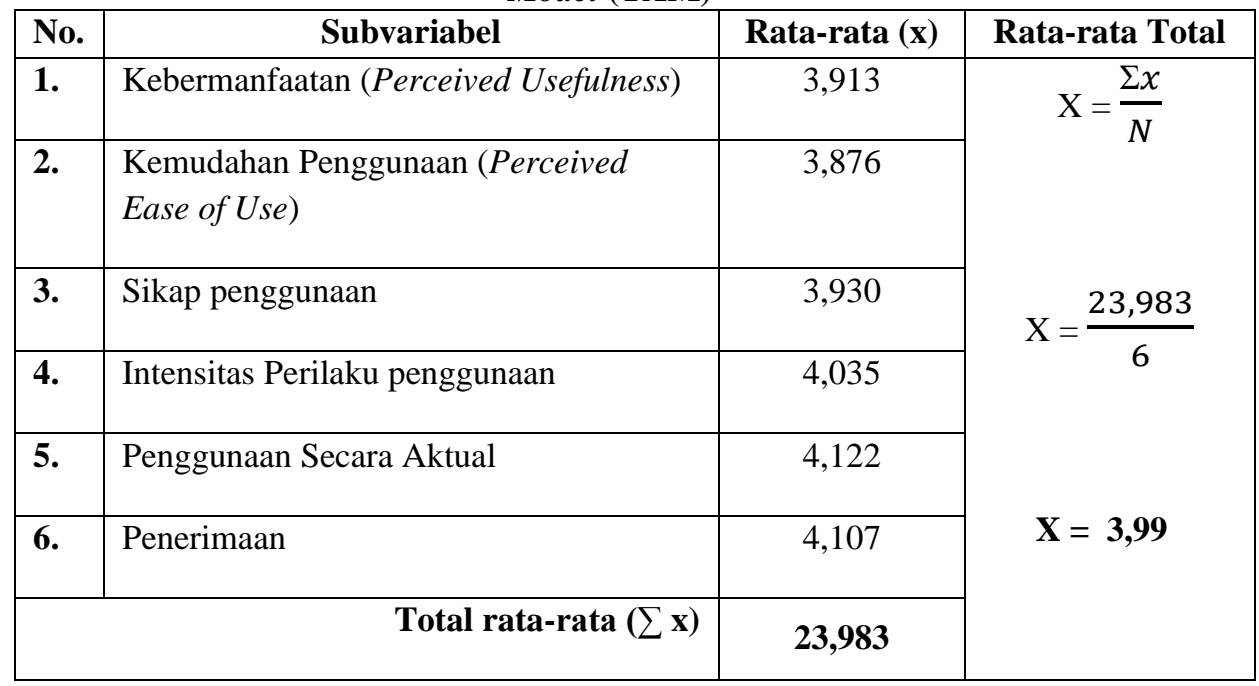

Sumber: Data Olahan Peneliti

Berdasarkan Tabel 4.41. grand mean variabel Technology Acceptance Model (TAM) menunjukkan angka 3,99 yang berada pada rentang 3,40 - 4,20 dengan kategori tinggi. Dengan demikian, tingkat penerimaan terhadap sistem otomasi ini dapat dikatakan tinggi.

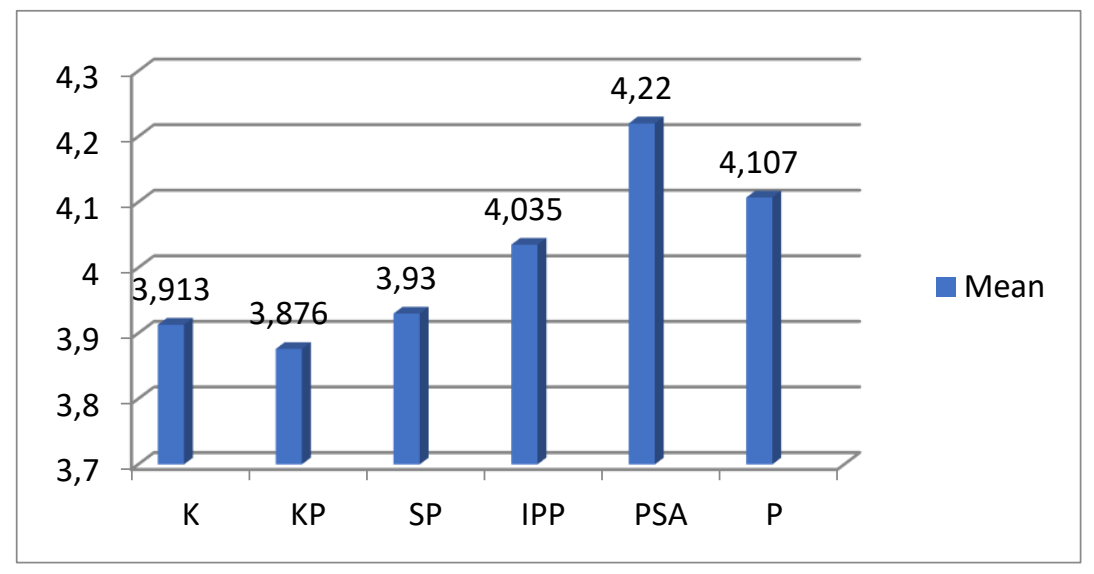

Grafik 7. Analisis Grand Mean Variabel Technology Acceptance Model (TAM)

Keterangan grafik:

$\mathrm{K} \quad=$ Kebermanfaatan

$\mathrm{KP}=$ Kemudahan Penggunaan

$\mathrm{SP} \quad=$ Sikap Pengguna

IPP = Intensitas Perilaku Pengguna

PSA $\quad=$ Penggunaan Secara Aktual

$\mathrm{P} \quad=$ Penerimaan

Penelitian ini dilakukan dengan dengan menggunakan teori Technology Acceptance Model (TAM). Dengan teori ini dapat diketahui hasil penelitian berdasarkan indikator-indikatornya. Bagaimana indikator tersebut dapat dikatakan memenuhi syarat penerimaan dan indikator apa saja yang perlu ditingkatkan untuk penerimaan sistem otomasi berbasis SLiMS. 
Berdasarkan hasil penelitian dan analisis data yang diperoleh, terdapat beberapa hal yang perlu dibahas bahwa sistem otomasi dapat mempermudah pengelolaan perpustakaan. Manfaat yang dirasakan pemustaka maupun pustakawan dapat berarti bahwa sistem otomasi tersebut dapat diterima di kalangan pemustaka

Temuan yang didapat oleh peneliti berdasarkan penyebaran angket kepada pemustaka di UPT Perpustakaan Politeknik Sriwijaya, untuk memperoleh data angket yang mengacu pada teori TAM dengan menggunakan subvariabelnya, yaitu persepsi kemudahan penggunaan, persepsi kebermanfaatan, sikap terhadap penggunaan sistem informasi, intensitas perilaku penggunaan sistem informasi, penggunaan sistem informasi secara aktual, dan penerimaan.

Pada subvariabel persepsi kemudahan pengguna, dari 8 pertanyaan didapatkan rata-rata hitung kseluruhan sebesar 3,913 dan tergolong dalam kategori tinggi. Jika dilihat dari angka ratarata keseluruhan dengan angka demikian, hampir seluruh indikator mendapat penerimaan tinggi dari responden atau pemustaka. Dari hasil yang di peroleh ada beberapa indikator yang mendapat nilai rata-rata rendah diantara yang lainnya adalah indikator 4 yaitu Menggunakan Senayan Library Management System dapat meningkatkan efektifitas kinerja. Indikator ini tergolong pada kategori sedang, meskipun masih tergolong baik, perlu ditingkatkan untuk keefektifan kinerjanya.

Subvariabel persepsi kebermanfaatan, menunjukkan perhitungan yang berbeda pula. Semua indikatornya berada pada kategori tinggi. Rata-rata dari 12 pertayaan berada pada angka 3,876 dan tergolong pada kategori tinggi. Sebagian besar responden tidak mengalami kesulitan dalam penggunaannya. Sangat banyak responden yang mencapai tujuannya dengan mudah menggunakan system otomasi. Kemudahan dalam penggunaan ini mengunggulkan SLiMS untuk banyak digunakan pada sistem otomasi perpustakaan.

Pada subvariabel sikap pengguna digunakan untuk mengukur sikap penerimaan atau penolakan pemustaka terhadap sistem otomasi yang digunakan. Pada subvariabel ini hanya terdapat dua pertanyaan dari satu indikator. Kedua pertanyaan mendapat rata-rata tinggi yaitu 3,93. Lebih dari $3 / 4$ responden menjawab setuju dan sangat setuju. Sikap penolakan dan penerimaan responden sangat terlihat kesimpulannya dari angka perhitungan rata-rata jawaban yaitu lebih condong kepada penerimaan. Subvariabel ini berkaitan dengan dua subvariabel sebelumnya. Sistem otomasi ini diterima para pemustaka tidak lain karena kemudahan penggunaan dan kebermanfaatan bagi para pemustaka itu sendiri. Memudahkan pemustaka untuk mencari informasi yang dibutuhkan, seperti mencari buku, jurnal dan lain-lain.

Beralih pada subvariabel intensitas perilaku pengguna, angka yang dihasilkan juga relatif besar. Lebih dari $3 / 4$ responden juga lebih sering menggunakan system otomasi daripada tidak. Responden sering menggunakan system otomasi karena fitur yang disediakan. Hal ini dapat dilihat pada pernyataan 2 pada angket. Responden sering menggunakan system otomasi untuk mencari informasi terutama untuk mengerjakan tugas kuliah dan tugas akhir. Responden sangat terbantu dalam hal efisiensi dan efektifitas dalam menyelesaikan pekerjaannya.

Subvariabel penggunaan secara aktual memudahkan peneliti untuk mengetahui bahwa pemustaka sangat sering menggunakan system otomasi ini. Terlihat pada pertanyaan kedua pada angket bahwa rata-rata responden mencapai angka 4,29 dengan predikat sangat tinggi. Artinya responden sangat setuju dan setuju dalam menyatakan penggunaannya terhadap system otomasi.

Subvariabel yang terakhir adalah subvaiabel penerimaan. Pada subvaribel ini hanya terdapat satu pernyataan yaitu "selalu mengakses system otomasi Senayan Library Management Sistem dengan bijaksana". Dari 100 responden hanya ada 8 yang menjawab ragu-ragu. Lebih dari setengah menjawab setuju dan selebihnya sangat setuju. Artinya system ini sangat diterima di kalangan pemustaka. 8 responden yang menjawab ragu pun bukan tidak pernah mengakses informasi dengan menggunakan SLiMS, hanya terkadang menggunakan dan terkadang tidak.

Mengacu pada perhitungan jawaban angket responden peneliti mengambil kesimpulan bahwa sistem otomasi menggunakan SLiMS dapat diterima dengan baik oleh pemustaka, hal ini ditunjukan dengan nilai rata-rata dari indikator TAM memperoleh nilai tinggi. Penerapan sistem otomasi sudah berjalan sesuai dengan tujuan dan manfaat yang diharapkan. Dengan demikian dapat dikatakan bahwa sistem otomasi ini memang diperlukan adanya untuk mencari informasi yang 
efektif dan efisien berdasarkan data angket yang disebarkan oleh peneliti. Hal ini menunjukkan bahwa teknologi informasi merupakan bagian yang tak terpisahkan bagi dunia perpustakaan terutama dalam era globalisasi saat ini.

Indikator dikembangkan dari subvariabel. Masing-masing subvariabel memiliki beberapa indikator sebagai tolak ukur penilaiannya. Soal-soal pada kuesioner yang telah disusun bersasarkan indikator dari setiap subvariabel telah memiliki masing-masing rata-rata jawaban dari 100 responden. Subvariabel yang memiliki rata-rata paling rendah adalah adalah subvariabel kemudahan penggunaan. Sementara rata-rata yang paling tinggi adalah subvariabel penggunaan secara aktual. Pada kasus ini, indikator yang memiliki nilai paling rendah adalah indikator efektifitas kinerja pekerjaan yang berada pada subvariabel kebermanfaatan dengan rata-rata 3,28 dengan kategori sedang. Dibandingkan dengan rata-rata indikator lain, inikator ini tergolong paling rendah meskipun masih berada pada kategori sedang. Artinya indikator pada subvariabel kebermanfaatan sistem otomasi di UPT Polsri perlu peningkatan.

\section{SIMPULAN}

Berdasarkan hasil pembahasan yang telah dipaparkan di atas yang dilakukan di UPT Perpustakaan Polsri didapat Grand mean technology acceptance model pada software Senayan Library Management System (SLiMS) memperoleh nilai tinggi hal ini dapat disimpulkan bahwa Software SLIMS dapat diterima dengan baik oleh pemustaka Perpustakaan Politeknik Negeri Sriwijaya. Terdapat satu indikator yang perlu ditingkatkan, yaitu indikator efektivitas kinerja pekerjaan pada subvariabel kebermanfaatan yang termasuk dalam kategori sedang.

\section{DAFTAR PUSTAKA}

Arikunto, S. (2010). Prosedur Penelitian: Suatu Pendekatan Praktik. Rineka Cipta.

Azwar, S. (2010). , Metode Penelitian. Cetakan Kesepuluh, (Yogyakarta : Pustaka Pelajar, 2010), 126. Yogyakarta: Pustaka pelajar.

Rahayuningsih. (2007). Pengelolaan Perpustakaan. Yogyakarta: Graha Ilmu.

Republik Indonesia. Undang-undang Republik Indonesia No. 43 Tahun 2007 (2007). Indonesua. Retrieved from https://www.perpusnas.go.id/lawdetail.php?lang=id\&id=170920114322Ir9g6HhRuc

Sugiyono. (2013). Metode Penelitian Pendidikan Pendekatan Kualitatif, Kuantitatif, dan $R \& D$. Jakarta: Alfabeta.

Yusuf, M. (2017). Metode Penelitian: Kuantitatif, Kualitatif dan Penelitian Gabungan. Jakarta: Kencana. 